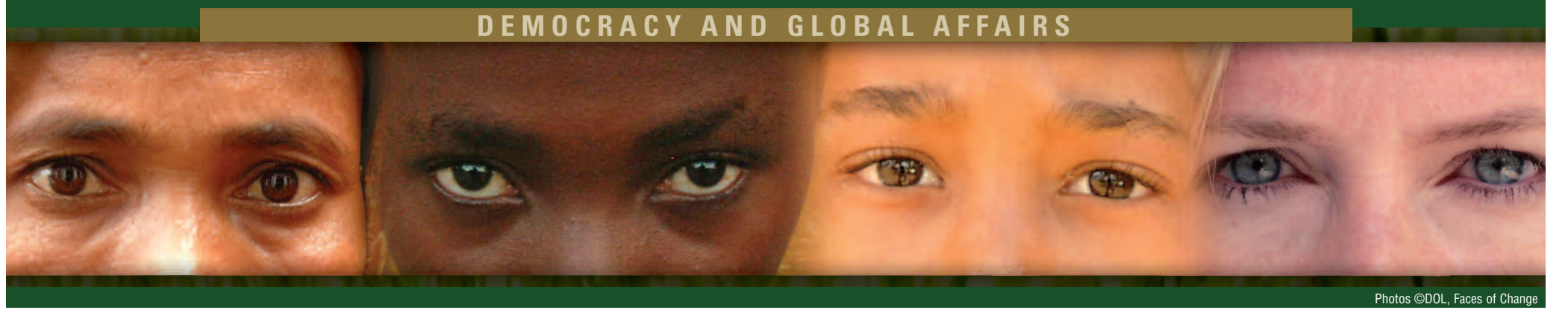

\title{
Facts About Human TrafFicking
}

\section{What is human trafficking?}

Trafficking in persons is modern-day slavery, involving victims who are forced, defrauded or coerced into labor or sexual exploitation. Annually, about 600,000 to 800,000 people-mostly women and children — are trafficked across national borders which, does not count millions trafficked within their own countries.

People are snared into trafficking by many means. In some cases, physical force is used. In other cases, false promises are made regarding job opportunities or marriages in foreign countries to entrap victims.

\section{What impact does human trafficking have on the world?}

Human trafficking is a multi-dimensional threat. It deprives people of their human rights and freedoms, it is a global health risk, and it fuels the growth of organized crime.

Human trafficking has a devastating impact on individual victims, who often suffer physical and emotional abuse, rape, threats against self and family, passport theft, and even death. But the impact of human trafficking goes beyond individual victims; it undermines the health, safety and security of all nations it touches.

\section{What is the United States doing to stop trafficking?}

Trafficking impacts many nations, including the United States. That's why the U.S. Government has taken a number

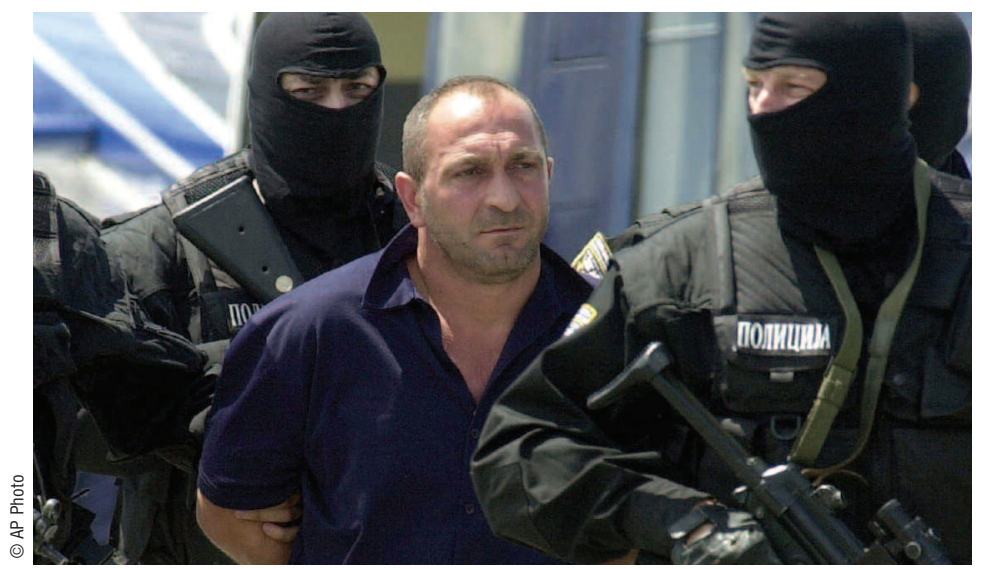

Convicted Macedonian trafficker

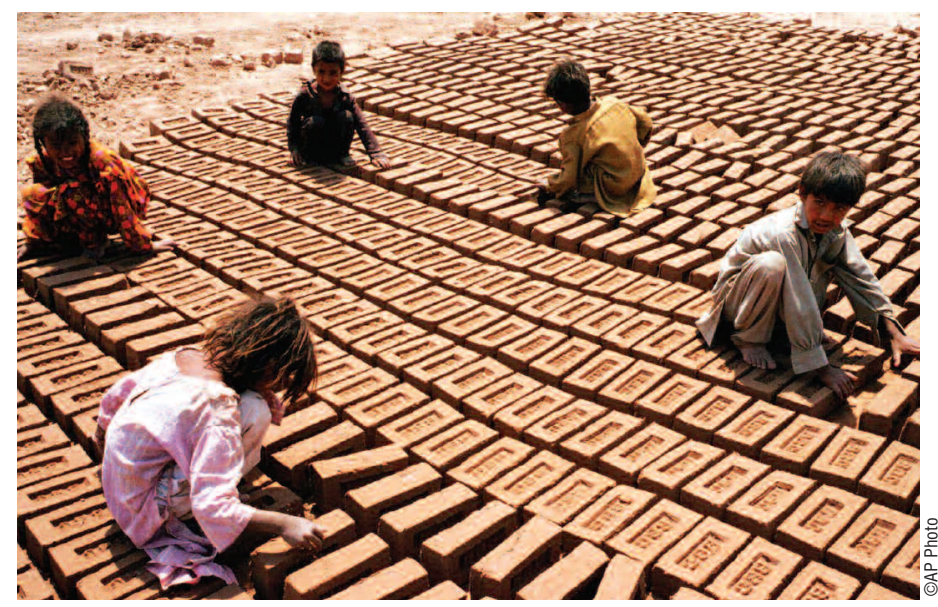

Abused children in South Asia

of serious and significant actions to combat trafficking occurring at home. A few examples of American efforts include: - Congress passed legislation so Americans who sexually prey on children abroad can be prosecuted and sentenced to as many as 30 years in prison.

- The Department of Justice has focused on increasing the number of trafficking victims rescued and the number of prosecutions and convictions of traffickers.

- The Department of Health and Human Services (HHS) is certifying trafficking victims so they may qualify for the same assistance available to refugees. HHS is also running a major public awareness campaign to alert victims in the U.S. that help is available through the hotline number 888.3737.888.

- The Department of Defense has implemented a zerotolerance stand against any actions by Defense personnel that contribute to human trafficking and is instituting a service-wide mandatory training program.

- The Departments of Labor and Homeland Security, USAID, and other government agencies are executing action plans to combat human trafficking.

\section{What is the U.S. doing to help other countries?}

Because human trafficking is transnational in nature, partnerships between countries are critical to win the fight against 
modern-day slavery. The U.S. is reaching out to other countries in a number of important ways:

v In a speech to the United Nations General Assembly, President Bush raised the issue of human trafficking and asked leaders of the world to work together to end it. In his 2005 inaugural address, the President said, "No one is fix to be a master, and no one deserves to be a slave."

- The State Department is working extensively with governments on action plans for prevention, protection of victims, and prosecution.

- Congress has strengthened anti-trafficking legislation and contributed more than $\$ 82$ million in funding last year for efforts abroad to end slavery. The U.S. is providing money around the world for:

- Rehabilitation and work training centers for victims

- Special housing shelters for victims

- Law enforcement training and legal reform assistance

- Information and awareness campaigns

- Voluntary repatriation for displaced victims

- Training for immigration officials, medical personnel and social workers

- Combating sex tourism

- Rescuing victims from slavery

\section{What needs to be done?}

When dealing with an issue of this importance and urgency, there is much to be done. The U.S. is asking governments to immediately take action to step up their anti-trafficking efforts:

- There is a critical need for increased rescues of trafficking victims and prosecutions of traffickers.

- People freed from slavery must be treated as victims of crime, not criminals.

- The demand for modern-day slaves must be stopped. When people quit buying trafficking victims, or quit using vicitms for pleasure or profit, the market for the trade in human life will dry up.
What are the Trafficking Victims Protection Act and the Trafficking in Persons Report?

Congress passed the Trafficking Victims Protection Act (TVPA) in 2000 and strengthened it in 2003. This law provides tools for the U.S. to combat trafficking in persons, both domestically and abroad.

One of the key components of the law is the creation of the Trafficking in Persons Report. The Department of State produces this annual report assessing government response in each country with a significant number of victims of severe forms of trafficking in persons. Countries in the annual report are rated in tiers, based on government efforts to combat trafficking.

\section{What do the tiers of the Trafficking in Persons Report mean?}

- Tier 1: Countries that fully comply with the act's minimum standards for the elimination of trafficking.

- Tier 2: Countries that do not fully comply with the minimum standards but are making significant efforts to bring themselves into compliance.

- Tier 2 Watch List: Countries on Tier 2 requiring special scrutiny because of a high or significantly increasing number of victims; failure to provide evidence of increasing efforts to combat trafficking in persons; or an assessment as Tier 2 based on commitments to take action over the next year.

- Tier 3: Countries that neither satisfy the minimum standards nor demonstrate a significant effort to come into compliance. Countries in this tier are subject to potential non-humanitarian and non-trade sanctions.

For more information, see the Web site of the State Department's Office to Monitor and Combat Trafficking in Persons at www.state.gov/g/tip.

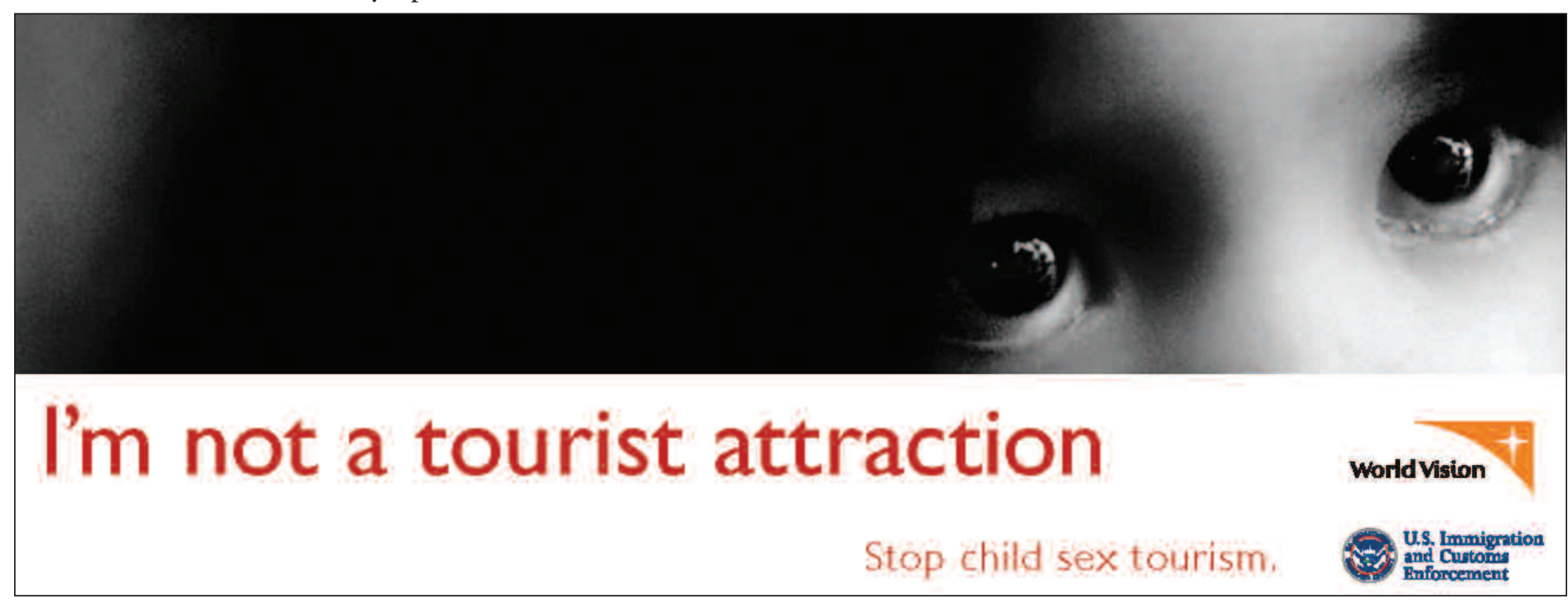

OWorld Vision 